\title{
Teachers' critical reflection: what are the practices for social justice in education?
}

\author{
Rola Koubeissy, Université de Montréal \\ Geneviève Audet, Université du Québec à Montréal
}

DOI : 10.51186/journals/ed.2021.11-1.e433

\begin{abstract}
This article explores teachers' participation in the school's social justice system through the lens of the critical multicultural approach (May \& Sleeter, 2010; May, 2000; 2003). Based on a research project about reconstruction and the theorization of teachers' stories of practice (Desgagné, 2005) in a multiethnic context, data was collected from teachers in highly multiethnic primary schools in Québec. They were asked to narrate a story about a problem or an event with an immigrant or refugee student in their class. Four of these stories have been selected for this article. Our aim was to analyze the teachers' cultural responses and their perception of their roles in supporting their students. Our analysis shows that although these teachers tend to make changes to their students' reality, they cannot escape or contest "alone" the norms of an academic, societal and political system that governs its power relationships and privileges, its dominant norms and values.
\end{abstract}

Keywords: critical multiculturalism, immigrant or refugee student, primary education, social justice, story of practice

\section{Résumé}

L'objectif de cet article est d'explorer, à la lumière de l'approche multiculturelle critique (May \& Sleeter, 2010 ; May, 2000 ; 2003), la participation des enseignant-es au système de justice sociale scolaire. À partir d'un projet de recherche sur la reconstruction et la théorisation des récits de pratique des enseignant-es (Desgagné, 2005) dans un contexte multiethnique, des données ont été recueillies auprès d'enseignant-es d'écoles primaires hautement multiethniques au Québec. Des enseignant-es ont été invités à raconter un récit lié à un événement ou à un problème qui s'est produit avec l'un-e de leurs élèves immigrant-es ou réfugié-es. Dans cet article, quatre récits narrés et reconstruits par quatre enseignant-es participant-es ont été sélectionnés et analysés. Nous visons à analyser de quelle manière les enseignant-es réagissent culturellement et assument leur rôle dans le soutien de leurs élèves. Notre analyse montre que malgré les efforts déployés pour changer la réalité de leurs élèves, 
les enseignant-es ne peuvent pas contrôler seuls les normes d'un système scolaire, sociétal et politique qui régit les relations de pouvoir et privilégie les normes et les valeurs dominantes.

Mots-clés : éducation primaire, élève d'origine immigrante ou réfugié, justice sociale, multiculturalisme critique, récit de pratique

\section{INTRODUCTION}

The migration that is taking place in Canada and many other countries challenges teachers to adopt effective and just practices for students from different ethnic, cultural, linguistic and religious backgrounds. As Banks (2006) stated, teachers must promote social inclusion so that all students can function as effective citizens in a diverse world and develop a positive attitude towards others. These citizens should also take on the responsibility for promoting the values and norms of social justice (Nieuwenhuis, 2010). This requires a transformation in the role of the educational system and its structures to become more inclusive. Thus, it is the school's role to support their teachers and create an environment that encourages students to critique the cultural norms, values and institutions that produce social inequities (LadsonBillings, 1999). The same challenge exists in the multiethnic context of Québec, the Frenchspeaking province in which our study took place. Mc Andrew, Audet, \& Bakhshaei (2016) argued that although teachers are making efforts to adjust their teaching to diversity, they need further training to adapt it fully to this reality.

In such a context, teachers' work becomes multiple; it consists of explaining, evaluating and developing new strategies and comprehensive resources to support the students' academic, social and cultural integration (Koubeissy, 2019). In addition, teachers must deal with the increasingly complex realities of discrimination, multilingualism and traumatization of war children (Potvin, 2017). How can teachers provide equal opportunities for all their students by participating in the school justice system in such a demanding context? By the school justice system, we mean that all constituent parts of the system work together to promote equity and social justice for students. As teaching for social justice lies at the heart of a democratic society (Grant \& Gibson, 2013), to what extent are the means of this concept embedded in the educational system? McLaren (2011) criticizes how schooling may inhibit students' access to tools necessary to see the world critically. He claimed that education is no longer considered a social responsibility but has been merchandised by many new businesses and companies. In this sense, multicultural education's transformational role in changing the structure of the school is not necessarily reflected in practices (Koubeissy \& Audet, 2021). Is multicultural education developing a school environment that reduces oppression, discrimination and racism? 


\section{PROBLEMATIC AND CONTEXT}

\subsection{Québec context}

In Québec, the educational reform of the 1990s was accompanied by many policies whose main focus was on diversity in schools and the linguistic and cultural integration of students. One such policy, the Policy Statement on Educational Integration and Intercultural Education, published in 1998 (MEQ, 1998), defines intercultural education as the ideal way to live together in a democratic, pluralist and francophone society in which social justice is one of its cornerstones. Moreover, it exhorts teachers to facilitate students' social and cultural integration, encourages them to value their own culture and the cultures of others (MEQ, 1998). The Policy on Educational Success, issued in 2017, aimed for a more inclusive approach, given that the growing diversity of the population presented new challenges for the educational system with respect to equity. One of its main measures addresses the role of the school team in supporting student wellbeing and learning in a safe, welcoming and inclusive school climate open to diversity (MEQ, 2017). An inclusive school climate requires, among other things, changes to the conventional role of the school, its policies and curriculum, the teacher's role, as well as the role of all school actors. The intent of the inclusive approach, defined as a continuous process, is to transform the attitudes and practices of institutions to take into account the diversity of needs and eliminate exclusion (Potvin, 2014). Based on the needs of students, services or practices are adjusted to ensure that students succeed (Potvin, 2014). Thus, it is the school system that adapts, not the students. Accordingly, teachers must implement these measures and policies in their classrooms that promote equity and social justice among their students. To adopt these inclusive practices, teachers require initial and in-service training and the support of a fully adapted system.

\subsection{Social justice and limits of the multicultural approach}

According to Kymlicka (2010), the multicultural approach is an inclusive model that rejects assimilation and pushes immigrants and visible minorities to abandon their ethnic identity and to adopt a new national identity. Likewise, Banks (1997) defined multicultural education as "a reform movement that is trying to change the schools and other educational institutions so that students from all social class, gender, racial and cultural groups will have an equal opportunity to learn" (p. 4). Embedding this in the school system and transforming the whole school environment to provide equal opportunity for all students is an ongoing process (Banks, 1997). May (1999), for example, argued that the multicultural approach has not lived up to its promise. It did not sufficiently alter the situation of minority students, the monocultural approach in school practices, and the processes of power relations and inequality which govern all these (May, 1999). According to May and Sleeter (2010), the principles of multiculturalism in education have been weakened, for example, the recognition and acceleration of intercultural respect in the school environment and consideration for racial 
and ethnic diversity. The regression in the role of the multicultural approach is due to many social, economic and political factors, one being the neoliberal governance that normalized the dominant narratives, ideas and values. This type of governance produced asymmetrical power relationships and legitimized inequity (Lea, 2010). May and Sleeter (2001) opined that multiculturalism could not address this problem because of its insistence on culture. For instance, Lea (2010) explained that multicultural education has not confronted hegemony in schools and society. McLennan (2001) went as far as to postulate that multiculturalism might be seen as a threat to powerful cultures, as its culture-focused themes leave little room for cultures to interact or adapt to the fundamental beliefs and practices of others.

In the same way, May and Sleeter (2010) have questioned the basis of this approach. They argued that whereas the approach believes that the root of the conflict is a misunderstanding of differences, the problem actually lies in inequitable power-grounded relationships. It essentializes culture and reduces it to an ensemble of concrete practices that ignore the broader social and political context. Thus, rather than going beyond the celebration of differences to address sensitive issues such as racism, oppression and inequality, this approach continues to engage in the superficial interpretation of differences, the distribution of power and in solving problems without digging deeply to explore their roots. Chan (2011) argued that this essentialism might encourage teachers to believe that students of a particular ethnic group have similar learning needs. Likewise, it creates stereotypes and presumptions that frame teachers' work and limits their interaction with students, consequently opening the door to unjust educational practices. Furthermore, it challenges teachers to respond in a culturally appropriate way to their students' diverse needs (Chan, 2011).

\subsection{Social justice and limits of the multicultural approach}

Teachers, as previously mentioned, are not only expected to deal with diversity and the integration of measures into their classrooms, but must also teach and plan for equity and social justice. To accomplish this, they must be mindful of their practices and question their actions through self-reflection. This could be challenging, as teachers presently feel overwhelmed by the directives (policies, plans, curriculum, evaluation, etc.) of an already demanding school system. Adding to this challenge may be a lack of information about their students' backgrounds and realities and a lack of experience teaching in a multiethnic context. Mc Andrew, et al. (2016) stated that although some teachers address human rights and intercultural relations issues in their classrooms, others still perceive their students' ethnic, linguistic, cultural and religious diversity as a threat to their Québec identity. Likewise, Audet (2011) found that some teachers are still wary about the increasing diversity among the student body. Other teachers may subconsciously reflect negative representations conveyed in society through their attitudes and teaching practices and make false assumptions about students' issues based on specific ethnic groups in their classrooms (Potvin, 2017). This 
means the debate is ongoing, and those teachers may not know how to adjust their role or adapt to the context.

Lea (2010) insisted it was the teachers' role to recognize how hegemony persists in schools, societies, and practices. She summarized the problem by explaining that "hegemonic narratives convince those of us who benefit from dominant institutional and cultural arrangements and those of us who are oppressed by them that these arrangements are 'natural'" (Lea, 2010, p. 33). This recognition is related to the concept of deficit thinking. Bishop (2010) saw that this concept represented a process for teachers, which involves surmounting obstacles to see the world differently and feel their practices as fair and just. In the context where neoliberal educational policies dominate, teachers may not be conscious of the reality of oppression and may accept this dominant structure (Macedo, 2018). In some cases, they have no purpose except those prescribed by their oppressors. Freire (1972) argued that education should be the starting point for critical reflection, so that teachers become aware of their students' reality and take action to transform it. This view also aligns with that of inclusive schools and inclusive practices.

This process of critical transformation, reflection and change cannot be done without students' engagement. To do so, teachers need to know their students, view them as allies in a common struggle for social justice (Gutstein, 2010) and be aware of the integration challenges they face. Rhedding-Jones (2010) considered that many teachers are aware of such challenges and opt for new forms of transformation to interrupt their students' assimilation. In a critical sense, teachers must realize that they should educate their students and learn from them. This critical view is absent from multicultural education. To avoid this debate and espouse a more comprehensive approach that allows us to do an in-depth analysis of our data, we use a critical multiculturalism approach to examine how the teachers' critical thinking process leads to change (Giroux, 2010).

\section{THEORETICAL FRAMEWORK}

\subsection{Social justice in education and critical multiculturalism}

Referred to the American literature as "teaching for diversity" or "culturally responsive pedagogies" (Boylan \& Woolsey, 2015), social justice is viewed as the heart of many approaches, such as the inclusive approach, the antiracist approach, critical multiculturalism and others. Nieuwenhuis (2015) stated that social justice in education should be based on a holistic approach that takes geo-historical and social contexts into account. This implies the necessity of considering the social reality of the situation within which social justice must be accomplished (Nieuwenhuis, 2015). It is also a conscious and reflective process (Carlisle, et al., 2006). Therefore, before adjusting all school practices and measures, the system's constituents should be redefined and critically evaluated. In this article, we favour the concept 
of teaching for social justice rather than teaching social justice. Teaching for social justice includes having students develop a critical perspective that questions relations of power and the existing social order so they can participate in the struggle for social change (Gutsein, 2010). Thus, it is an oriented goal for empowering students (Lea, 2010).

Critical pedagogy and multicultural education complement each other (Chan, 2011; McLaren, 2011; May \& Sleeter, 2010) since critical pedagogy is grounded in social justice and equality (Chan, 2011). This approach aligns with critical multiculturalism developed in the 1990s as a theoretical framework to create critical consciousness and equitable educational practices. This approach "gives priority to structural analysis of unequal power relationships, analyzing the role of institutionalized inequities, including but not necessarily limited to racism" (May \& Sleeter, 2010, p. 10). This process leads to social justice in education, where both teachers and students construct meaning out of the situations experienced in their classroom by analyzing them and adapting them to fit their needs. May (2000) identifies some characteristics of critical multiculturalism: as acknowledgment of the role of ethnicity and culture in the development of social and political identities without essentializing them; recognition of unequal power relationships; deconstruction of the apparent neutrality of civism, the set of dominant values and practices; and maintenance of critical reflexivity of specific ethnic and cultural practices. Lea (2010) stated that it is a necessary response to hegemonic narratives rooted in the educational system and a framework for teachers to identify hegemonic discourse and develop strategies to transform it. It is a critical process that deals with the various forms of inequity embedded in the educational system and a tool that empowers students and teachers to be engaged in culturally responsive practices (Ukpokodu, 2003, cited in Flynn, 2010). This approach urges teachers to reflect on what and how they teach (Nieto, 1999). It is about transforming practices that belong to the dominant culture into practices appreciated by others from different cultures (Rhedding-Jones, 2010). In that sense, Freire $(1970,2018)$ criticized what he called banking education, where the students are seen as ignorant and passive. For him, education is for liberation. He encouraged a critical approach in which students and teachers can read the reality of the situation and engage in a social process that promotes equity and social justice. Similarly, Lea (2010) criticizes how the one-size-fits-all teaching approach, which is promoted by standardized textbooks and neoliberal policies, prevails in all classrooms and reduces multicultural education to some visible aspects of culture. For this reason, bringing critical multiculturalism into schools implies reflecting and adapting practices and situating them in an environment that evolves, according to the various cultures represented by students (Rhedding-Jones, 2010). Thus, education should commit to preparing students to critique and question the existing social order to allow them to participate in the fight to change it (Gutstein, 2010). Based on their own experiences, they should also participate in the critical analysis of situations through a dialogue that values their voices (Stokke \& Lybæk, 2018). 


\subsection{The competent actors}

Given the challenges teachers may face in managing diversity, adopting inclusive practices and promoting social justice in their classes, we opt to consider their point of view and give them a voice to understand how they cope with the school system. To be able to understand how they deal with a situation involving one of their immigrant or refugee students, we refer to the concept of practitioners as "competent" actors (Giddens, 1987). In his theory, Giddens defined a "competent" actor as one who, because of a self-attributed "feeling of competence", has the power to "act" and empower himself in the face of what he perceives as constraints that limit his range of possible actions. Therefore, an actor uses the "power of action" to respond to structures and directives. Giroux (2010) so far as to propose a power to act rooted in critical pedagogy. Indeed, for him, teachers must question the unequal power relations that exist. This requires restructuring and changing their role (Apple, 2011). However, despite the publication of many policies and plans favouring an inclusive approach, there is little evidence that the role of teachers is changing. Giroux (1988) questioned the whole system for failing to consider the teachers' role in their students' active learning process. He cited two problems that disempower teachers. First, the proletarianization of their work and the tendency to reduce teachers to the status of a technician rather than developing their role in improving critical curriculum; and, the second, absence of the school's role as a democratic place to transform practices.

Thus, the data we collected will be explored from this social justice and critical multiculturalism approach, that recognizes teachers as competent actors.

\section{METHODOLOGY AND ANALYSIS}

Based on a research project on the reconstruction and theorization of elementary teachers' stories of practice (Desgagné, 2005) in a multiethnic context in Québec, this article analyzes teachers' cultural responses and their perceptions of their roles in supporting their students. Data were collected from 18 teachers in highly multiethnic primary schools in Québec using 60 minute long explicitation interviews (Vermersch, 2017). Teachers were asked to narrate a story related to a problem or an event that happened with one of their immigrant or refugee students in the class. An interactive session to explain the project to the participants took place before the interviews. Inspired by the use of the critical method in research (Freire, 1971; Kincheloe, et al., 2011), which asserts the role of teachers as partners in the research, the collected stories were reconstructed in chronological order by the researcher and then validated by the teachers. For this article, four stories were selected because of their attempt at explaining the teachers' actions in dealing with an immigrant or refugee student and reveal not only teachers' perceptions of their roles, but also how they justified this role.

The corpus was analyzed using the critical multiculturalism approach (May, 2000; 2003; May \& Sleeter, 2010). We undertook two overlapping levels of analysis. The initial analysis 
extricates the actions of the participants through their narration of the situation. The second level of analysis, which focuses more on the story's progression, reveals how they reflect on their role. It is as if the teachers define their competence and see themselves as proficient within their work context. Subsequently, the results are presented for each of the two levels of analysis, and the participants' stories of practices are cited. Pseudonyms have replaced teachers' real names and italics are used to report what they said. These reports have been translated into English by the authors.

\section{RESULTS}

\subsection{Teachers' actions in dealing with the situation}

Alexandre, a Grade 5 teacher, with ten years of teaching experience in different schools, was worried about the last-minute arrival of Veronica, an immigrant student from Cuba: "It was not as if a new student from Québec arrived and all we had to do was to prepare a desk." He decided to give her time to "adjust." Then, around mid-September, afraid she was falling behind, he allocated time to take care of her. As he thought the Grade 5 textbook did not fit Veronica's needs, he asked a colleague from another grade level to share some French material with him. He had also developed some new materials with the help of the language support teacher, and drawn up a personalized academic plan for Veronica. He explained he had to prepare a specific schedule every morning for her to work on: "It was a big job for me." At the same time, he encouraged her to focus on her strengths: "Since she was making incredible drawings on the computer, I suggested [...] to show them to others". However, Veronica wasn't totally engaged; Alexandre said she was "upset" as she expected to be in Grade 6 rather than Grade 5, but he never discussed this issue with her. Because of all these challenges, he mentioned she was in "survival mode". This seemed to be, not only due to the last-minute arrival of the student, but also to the fact that she was an immigrant: "I did not expect to welcome an allophone student." He explained that he didn't have "information about her", but he tried to do the best he could.

Gigi, also a Grade 5 teacher with more than ten years of experience, was convinced that Jonathan, a francophone immigrant who arrived in Québec at the end of February with his father and sisters, but not his mother, needed time "to adapt". It started quite well: "Jonathan was doing his tasks". However, things began to change about two months after he arrived: "In the morning, he came to the class tired. [...] He wasn't doing his homework anymore, and I felt like he was lost". After observing his behaviour for some time, Gigi and the remedial teacher decided to report Jonathan's situation to the Director of Youth Protection (DYP). At the same time, Gigi noticed that Jonathan had some academic difficulties and was weaker than others in the class: "I did all I could to help him. I had already bonded with him; we talked to each other often, even though he wasn't talkative". At the end of the school year, she expressed her concerns as Jonathan had not shown any positive change in his attitude: 
"I felt so helpless! I still did everything I could with the remedial teacher". The following year, Jonathan did not show up. Gigi explained that she was not sure what had happened to him until she received an invitation from the DYP to meet him: "I was really surprised! It touched me that he wanted to see me again and that the bond I had tried to forge with him over just a few months had touched him". She said she met with him numerous times while he was under supervision.

Likewise, Melanie, a Grade 2 teacher in a school in a very disadvantaged area, thought Oumar, who had just arrived in Canada with his mother to join his father, "needed time to recover from his culture shock and adjust to his new life". Melanie soon realized that Oumar had some academic difficulties. He was unmotivated and started acting out. She talked to her colleagues to "figure out how to calm him down and provide structure for him". She explained: "I was physically and psychologically exhausted because I was always looking for solutions". In class, she tried "to please him by valuing his previous experience in his country", but he responded negatively, even crying once when she talked about his country. Melanie realized that certain class activities made Oumar feel incompetent, so she tried finding new activities, such as robotics and programming, to make him "feel competent". Besides his academic challenges, Oumar was anxious as he did not have friends outside of school. She tried to establish links with a neighbourhood community organization that offered a homework assistance program, sports activities, and games twice a week to support him. Melanie explained that throughout the year, she "tried to help Oumar" as she "was convinced of certain fundamentals: believing in the potential of all students and looking for a way to motivate the differentiated student".

To prepare her elementary Welcoming Class for the arrival of Syrian refugee students, Simone, who had 13 years of experience, decided to read a story to her students about war, even though the story was not part of the curriculum: "My intention was to tell a story that all children could relate to". While discussing the story, she said that all the students related it to their own countries: "I was happy and proud of myself because that meant that my story was truly universal". At the end of the story, "there was a resounding silence". She said she hesitated to ask them if they had comments, but "this was the primary intention of this reading: to talk about a sensitive subject, the war". When they did start talking, she was "very confused" about the narratives of some students: "A story of cannibalism emerged from this activity! And, all the kids had something to say about humans killing and eating each other." She reacted "quickly": "I had time to recap, to say that we are safe here and that these things don't happen in Québec and that no one ever eats anyone here". Despite her students' reactions, Simone was "convinced" that what she did was "necessary": "I always create an atmosphere where all subjects can be discussed". Later the same year, Simone developed a follow-up writing activity with her students, which she does every year. She explained that she asked students to write about their migratory journey in the form of a fairy tale, allowing them to express themselves and for her to get to know more about them. 


\subsection{Teachers' perceptions of their role and teacher competence}

The analysis of the four stories led to the conclusion that the teachers had different perceptions of their role in supporting their students. It was also apparent that the teachers associated their teaching competence to their actions.

Teaching students "from other countries that speak another language" is "not evident" for Alexandre who was doing "the best he could". It seems that his responsibility is embodied in a belief that his students' integration is not only his responsibility but also a "collective action", especially as he is "not trained to work in such a context". He said: "I'm not the only actor working for this child [...]. It's teamwork, and I don't want to see myself alone in this." This conviction that there are "other actors and elements" in the students' lives that he "cannot control" seems to relieve him of "guilt". He explained: "so, if this kid isn't progressing the way I want, I'm not the only one who is responsible." In articulating this, Alexandre seems to be redefining his sense of competence: he declared that teachers feel "incompetent" because they question whether what they are doing for immigrant students is enough to allow them to progress. However, they are not "the only ones responsible for their progress".

Throughout her story, it appears that Gigi defined her role as one that provides a safe environment in which students can express themselves: "We need to build trust in the classroom so that the students are comfortable talking to us". As she created a bond with Jonathan that remained after he left school, she did not feel like "a failure, as she could not have done more than what she did" She believed that small actions matter: "it's not necessarily extraordinary gestures that matter. You have to be yourself and trust your heart. It is the human side that is important!". The way she defined her role was rooted in her understanding of what immigrant families or refugees face before they arrive in their new country: "Some people went through really difficult times before they arrived". She also argues that "the teacher-student relationship is not something that can be learned through training".

On the other hand, it looks like Melanie believes it is the teacher's responsibility to engage students: "It was my responsibility to find out what he needed to make it happen. One of my main values was to believe in the potential of Oumar and others, too". Based on this belief, she questioned the role and responsibility of other teachers' in dealing with her student's situation: "During the year, we (teachers) never discussed what our responsibility was in this situation. It's as if everything that happened was Oumar's fault". As she didn't "feel any openness on the part of the administration", she decided to "work on her own". It seems she assigned herself a role that went beyond the limits of the curriculum: "some teachers are afraid to close the workbook and do things differently"; a role that takes into consideration the reality of her students and that reflects her awareness and her inclination to transform limits to opportunityies: "it was important to observe the students and treat differences as assets in 
the classes and not as a constraints". She also believes in dialogue and in engaging students to be aware of the reality and to appreciate differences: "You have to discuss the differences with the students and name them (languages, religions, etc.)".

Simone seems to define her role through building a relationship with her students and listening to them to help them overcome their trauma: "We need to listen to them; We cannot solve their problems on our own. If I do not listen to my students, their issues will not be solved". Although she mentioned this is not the role she wants, Simone seems to define teaching competence when she explained that a "good teacher" must consider the particularity of teaching in a diverse context: "When working with children from all over the world, you have to be open to these things and not deny the terrible events that are happening elsewhere. Otherwise, we won't be able to do a good job". It seems this role is shaping her professional identity: "Every time a student tells me a story like this, it's not my story, but it helps build my identity. This is how our experience is created". This connection with her students' lives is also affecting her personal life: "The gravity of certain unacceptable situations plunges us into an existential depression. You have to know how to build a shell ... but it always affects our psychological health, whether we are aware of it or not." At the same time, it appears she is precautious, especially when her discussions with her students felt "out of control". She explained her feelings: "This is the moment, in the middle of the action, when we ask ourselves whether we are right to go and play on this field, perhaps because of a lack of experience".

By describing teacher competence as a belief in collective responsibility (Alexandre); in being aware and transforming limits to opportunities (Melanie); in being aware and listening to students (Simone), and by developing trust and dialogue in class (Gigi), the teachers reveal, through their stories, that their actions to support their students.

\section{DISCUSSION: TOWARD A CRITICAL MULTICULTURAL PERSPECTIVE}

Through their stories, it is apparent that the teachers are contributing, in their own way, to create conditions in which they can support their immigrant or refugee students. They mentioned they couldn't have done more than they did. It seems this may have had some repercussions on their wellbeing as they felt "in survival mode" (Alexandre), "helpless" (Gigi), "physically and psychologically exhausted" (Melanie), "depressed" and "confused" (Simone). They also "lack experience" and are "not well trained" to deal with such situations. It seems they have to deal with all these situations in a school system that is neither particularly inclusive nor contributing to social justice. To better understand these teachers' critical experiences in this context, we discuss their stories using three lenses from the critical multicultural approach (Lea, 2010; May \& Sleeter, 2010): Dialoguing and giving voice to students; Culturally responsive teaching; Addressing hegemony in self, school and society. 


\subsection{Dialoguing and giving voice to students}

Moodley (1999) stated that critical students must be allowed to express themselves and talk about their stereotypes in class. In her story, Simone tends to bring forward "sensitive issues" for discussion. Believing in the importance of being aware and listening to her students, she develops a classroom environment where students can talk about anything and everything. Freire (2018) highlighted that it is not enough for the critical teacher to notice or assume an oppressed situation but must act with the student through constructive dialogue. Both the teacher and the student need to reflect on the situation to develop a culture of trust (Freire, 1970, 1974, 2018). Although Simone knows that many teachers avoid raising these topics because they find managing the conversation around them challenging, she transforms discussion into learning and opportunities for reflection so all her students can break the "taboos." She says this is also the purpose of the writing activity she developed to encourage her students to express and narrate their own stories. By doing this, she promotes their inclusion by engaging them in a critical process of self-expression and reflection on reality.

This is not necessarily the case with all the participants. Many factors may influence this dialogue generated between the teacher and the student, and the idea of "giving voice". Nieto (1999) considered that schooling for culturally and linguistically dominated students does not occur under the best conditions. He argued that the student's voice is absent from most analyses of multicultural education (Nieto, 1999). In a certain way, Jonathan, Oumar and Veronica were voiceless in relation to the system despite their teachers' efforts and actions to support them. This is the result of a school system that doesn't consider students' voices. Citing Freire $(1970,2018)$ this relates to banking education, where the students are seen as ignorant and passive social actors without any power to develop their critical conscience. Nieto (1999) pointed out that students should be consulted about schools' policies as they affect them the most. These policies could have an impact on these students' inclusion and their sense of belonging. For instance, Veronica wasn't consulted before being placed in Grade 5. In his story, Alexandre said that he did not bond with Veronica. He said he knew that she was upset about being in Grade 5, but they never discussed it. He focused on pedagogical support and language learning instead of empowering the student to question the existing system and negotiate her situation. This teacher-student relationship abolishes the transforming power of knowledge (Freire, 2001). Some teachers are unaware that they are fully overwhelmed by ministerial and institutional directives that serve only the interest of the structure in place. This restricts them from reading the world outside their classes.

\subsection{Culturally responsive teaching}

A critical multicultural approach supposes that all knowledge should be taught critically (Nieto, 1999) and that teachers should be culturally relevant. Seen as a practice promoting social justice, Ladson-Billings (1999) defined culturally relevant pedagogy as a pedagogy of 
opposition committed to collective empowerment that rests, among other criteria, on the importance of developing students' critical consciousness through which they challenge the status quo of the current social order. The teachers' stories reveal that they increased their marge de manoeuvre and developed what they perceived as relevant practices to respond to their students' needs. Everything indicates that Simone was aware of this. She looked for a story related to her students' reality and a writing activity that allowed them to express their feelings and talk about their migratory journey. She decided to go beyond the prescribed curriculum and choose a different story. Citing Flynn (2010), Simone structured a critical multicultural activity and decided to go above and beyond monocultural practices (RheddingJones, 2010). This is what Melanie decided to do to help Oumar integrate. She knew he liked robotics and that his father was an engineer, so she built on this reality and developed a new activity around his interest. Not only did she recognize this difference, but she built on it to create a learning activity for the whole class. Gigi was also motivated to support Jonathan to the point where she maintained a good relationship with him the following year. Alexandre also challenged himself to find new topics and exercises that were different from the curriculum. He also explained how he invested in Veronica's artistic abilities to support her integration. Culturally relevant teachers use a student's culture as a vehicle for learning (Ladson-Billings, 1999). These teachers are questioning the prescribed curriculum and acting to make specific changes in their practices according to their perceptions of their roles and their feeling of competence.

However, culturally responsive teaching entails a long process that requires other actors from the school and the school system itself to adapt. The teachers should be empowered and critical to challenge students to learn how to critically negotiate the world around them (Macedo, 2018) and understand the hidden dominant ideologies instead of being just taught to read and write (Freire, 1970; 2001; 2018; Kincheloe, et al., 2011). For this reason, going beyond the curriculum shouldn't be a goal in and of itself but should also aim to challenge other actors and constituents of the system to transform the social order for the sake of their students. For instance, Gigi described her role as building trust and dialogue with Jonathan, and she maintained a relationship with him. She had signaled his situation to the DYP. However, in her story, she mentioned that she was concerned as Jonathan had not shown any positive change in his attitude. It could be that Jonathan's situation required more than just the teacher's actions and that simply recognizing his reality was not sufficient to break the status quo, other factors control the situation.

\subsection{Addressing hegemony in self, school and society}

What does our reflection on these narrated stories reveal about teachers' practices, roles, and how they address them? Do they use deficit lenses to justify their actions? Or, in other words, are they blaming the students or their families for their challenges in helping them integrate? Lea (2010) mentioned that when teachers engage in reflection, they recognize 
hegemony in themselves, school, and society with respect to the students and try to undo deficit thinking. In her story, Melanie blamed the system and her colleagues for their deficit actions: "It's as if everything was Oumar's fault". She added that she did not feel "any openness" on their part, so she worked independently. She was aware that Oumar was experiencing cultural shock and that he needed time to adapt. In using this anti-deficit discourse (Patton Davis \& Museus, 2019) and in criticizing her colleagues' discourse, Melanie addresses the hegemony in school and gives voice to Oumar. Simone is beginning to break the cycle of hegemony by using stories and tools from outside the formal curriculum that simply reflects the dominant group's values, norms, and language. It seems like the teachers are redistributing the unequal power relationships reproduced by the institutional system. By taking this stance, both teachers' actions had some of the characteristics of critical multiculturalism, such as recognizing unequal power relationships and the deconstruction of dominant values and practices (May, 2000).

On the other hand, all the teachers mentioned that the students had newly arrived and needed time to understand what is happening and adapt. That means that they are aware that the school system, the policies, the language of instruction, the curriculum and the resources are not suited to fit these students' reality. For example, an institutional decision forces Alexandre to accept a student in his class 15 minutes before the beginning of the first school day. Thus, having to act on this last-minute decision, he chose to give Veronica time to adapt until he was prepared to deal with the situation. It is apparent that the teachers try to compensate for the shortfall caused by the school system itself. However, compensatory activities may remain superficial and limited to the formal curriculum and the societal system outside the class, and the distribution of power in this system is not questioned by the teachers. In addition, these activities risk essentializing students' culture and identities. In fact, on one occasion, when Melanie initiated class discussions relating to Oumar's country of origin, he was reduced to tears. Although Melanie describes in her story "difference as an asset", which reflects her appreciation of diversity, her action might result from essentialism that negatively affects Oumar's inclusion. Oumar feels culturally disconnected rather than engaged. As Chan (2011) stated, essentialism creates stereotypes and presumptions that frame teachers' work. This may inhibit teachers from addressing the hegemony found in school, and society and believing, as Lea (2010) mentions, that the societal arrangement is normal. This is how deficit thinking is created.

\section{CONCLUSION}

In general, it is apparent that the teachers go beyond the prescribed curriculum and expand their marge de manoeuvre to act in a more responsive way to provide additional support to their students. Moreover, some of their actions show that they transform the limits and constraints of the context into learning opportunities. They outsmart the school system to achieve some of their objectives. Referring to Giddens (1987), the teachers, because they feel 
competent, empower themselves to go beyond the structures and the directives to create opportunities. They do the best they can to overcome the limits. Are teachers devising equitable teaching practices to promote social justice? In light of the critical multicultural approach, this article explores teachers' participation in the school justice system by analyzing their stories to see how they supported their students' integration. Throughout the article, teachers were given a voice to narrate their actions. Are they critical multiculturalist teachers? Our analysis shows the answer to such a question is not evident. Although these teachers tend to change their students' reality, they cannot escape or contest "alone" the norms of an academic, societal and political system that governs power relationships and privileges its dominant norms and values. It is not fair to interrogate these teachers' promotion of social justice in education without questioning the mainstream curriculum and the institutional set of prevailing norms and values. Whereas these teachers participate in the justice system, they do not have control over all the factors in the field. The analysis shows that teachers' interventions are based on experience and an awareness (Freire, 1972) of their students' reality. They are mindful of the need to go outside the prevailing hegemony and deconstruct the deficit thinking mindset.

\section{REFERENCES}

Apple, M. W. (2011). Global Crises, Social Justice, and Teacher Education. Journal of Teacher Education, 62(2), 222-234. https://doi.org/10.1177\%2F0022487110385428

Audet, G. (2011). L'interculturel en classe : pour une prise en compte de la spécificité culturelle dans l'intervention. McGill Journal of Education/Revue des sciences de l'éducation de Mc Gill, 46(3), 1-16. http://dx.doi.org/10.7202/1009176ar

Banks, J. A. (1997). Multicultural Education: Characteristics and Goals. In J.A. Banks, \& C. A. McGee Banks (Eds.), Multicultural Education: Issues and Perspectives (pp. 3-31). Boston: Allyn and Bacon.

Banks, J. A. (2006). Improving Race Relations in Schools: From Theory and Research to Practice. Journal of Social Issues, 62(3), 607-614. https://psycnet.apa.org/doi/10.1111/ j.1540-4560.2006.00476.x

Bishop, R. (2010). Discursive Positioning and Educational Reform. In M. Stephen, \& C. E. Sleeter, (Eds.), Critical Multiculturalism: Theory and Praxis (pp. 61-72). New York, NY: Routledge.

Boylan, M., \& Woolsey, I. (2015). Teacher education for social justice: Mapping identity spaces. Teaching and Teacher Education, 46, 62-71.

https://doi.org/10.1016/j.tate.2014.10.007

Carlisle, L. R., Jackson, B. W., \& George, A. (2006). Principles of Social Justice Education: The Social Justice Education in Schools Project. Equity \& Excellence in Education, 39(1), 55-64. http://dx.doi.org/10.1080/10665680500478809 
Chan, A. (2011). Critical multiculturalism: Supporting early childhood teachers to work with diverse immigrant families. International Research in Early Childhood Education, 22(1), 63-75.

Desgagné, S. (2005). Récits exemplaires de pratique enseignante. Analyse typologique. SteFoy : Presses de l'Université du Québec.

Flynn, J. E. (2010). Discussing Race and Culture in the Middle-School Classroom: Scaffolding Critical Multiculturalism. In M. Stephen, \& C. E. Sleeter (Eds.), Critical Multiculturalism: Theory and Praxis (pp. 165-176). New York, NY: Routledge.

Freire, P. (1970). The Adult Literacy Process as Cultural Action for Freedom. Harvard Educational Review, 40(2), 205-225.

https://doi.org/10.17763/haer.40.2.q7n227021n148p26

Freire, P. (1971). Conscientisation. Recherche de Paulo Freire. Colmar : Éditions d'Alsace.

Freire, P. (1972). Education: domestication or liberation. Prospects: quarterly review of education, II(2), 173-181.

Freire, P. (1974). La pédagogie des opprimés. Paris : Maspero.

Freire, P (2001). Pedagogy of Freedom: Ethics, Democracy, and Civic Courage. Lanham, MD: Rowman and Littlefield Publishers, INC.

Freire, P. (2018). Pedagogy of the oppressed (50th ed.). London: Bloomsbury Academic.

Giroux, H. (1988). Teachers as intellectuals: toward a critical pedagogy of learning. London: Bergin \& Garvey.

Giroux, H. (2010). Rethinking Education as the Practice of Freedom: Paulo Freire and the Promise of Critical Pedagogy. Policy Futures in Education, 8(6), 715-721. https://doi.org/ 10.2304\%2Fpfie.2010.8.6.715

Giddens, A. (1987). La constitution de la société. Paris : Presses universitaires de France.

Grant, C. A., \& Gibson, M. L. (2013). 'The path of social justice': A Human Rights History of Social Justice Education. Equity \& Excellence in Education, 46(1), 81-99. https://doi.org/ 10.1080/10665684.2012.750190

Gutstein, E. (2010). Critical Multicultural Approaches to Mathematics Education. In M. Stephen, \& C. E. Sleeter (Eds.), Critical Multiculturalism: Theory and Praxis (pp. 127-138). New York: Routledge.

Kymlicka, W. (2010). État actuel de multiculturalisme au Canada et thèmes de recherche sur le multiculturalisme canadien 2008-2010.

https://www.bibliotheque.assnat.qc.ca/DepotNumerique_v2/AffichageFichier.aspx? idf $=13143$

Kincheloe, J., McLaren, P., \& Steinberg, S. (2011). Critical Pedagogy and Qualitative Approach. In N. Denzin, \& Y. Lincoln (Eds.), The Sage Handbook of Qualitative Research (pp. 163-178). Thousand Oaks, CA: Sage Publications.

Koubeissy, R., \& Audet, G. (2021). Towards critical teaching in a multi-ethnic context for a just integration of minority students. In V. Alves, \& B. da Silva (Eds.), Access to Justice in the Americas (1st edition, pp. 419-442). https://doi.org/10.53080/forjus-ajam 
Koubeissy, R. (2019). Enseigner dans un milieu multiethnique : pratiques de soutien des enseignants auprès d'élèves immigrants. Québec, QC : Presses de l'Université Laval.

Ladson-Billings, G. (1999). But That's Just Good Teaching! The Case for Culturally Relevant Pedagogy. Theory into Practice, 34(3), 159-165.

https://doi.org/10.1080/00405849509543675

Lea, V. (2010). Empowering Preservice Teachers, Students, and Families Through Critical Multiculturalism: Interweaving Social Foundations of Education and Community Action Projects. In M. Stephen, \& C. E. Sleeter (Eds.), Critical Multiculturalism: Theory and Praxis (pp. 33-46). New York, NY: Routledge.

Macedo, D. (2018). Introduction to the 50th Anniversary Edition. In P. Freire (Ed.), Pedagogy of the Oppressed (50th ed., pp. 1-33). London: Bloomsbury Academic

May, S. (1999). Introduction: Towards Critical Multiculturalism. In S. May (Eds.), Critical Multiculturalism: rethinking multicultural and antiracist education (pp. 1-10). London: Falmer Press.

May, S. (2000, April 24). Multiculturalism in the 21st century: challenges and possibilities. Presented at Annual Meeting of the American Educational Research Association, New Orleans, USA. https://eric.ed.gov/?id=ED441742

May, S. (2003). Critical multiculturalism. In M. Peters, C. Lankshear, \& M. Olssen (Eds.), Critical Theory and the Human Condition: Founders and Praxis (pp. 199-212). New York: Peter Lang Publishing Inc.

May, S., \& Sleeter, C.E. (2010). Introduction. Critical Multiculturalism: Theory and Praxis. In S. May \& C.E. Sleeter (Eds.), Critical Multiculturalism: Theory and Praxis (pp. 1-18). London: Routledge.

Mc Andrew, M., Audet, G., \& Bakhshaei, M. (2016). Immigration and Diversity at School: An Assessment. In C. Kirkey, R. Jarett \& S. Gervais (Eds.), Quebec Questions: Québec Studies for the 21st Century (pp. 297-315). Don Mills: Oxford University Press.

McLaren, P. (2011). Revolutionary critical pedagogy for a socialist society: A manifesto. The Capilano Review, 3(13), 61-66.

Mclennan, G. (2001). Can there be a 'critical' multiculturalism? Ethnicities, 1(3), 389-422. https://doi.org/10.1177\%2F146879680100100306

Ministère de l'Éducation du Québec (MEQ). (2017). Policy on Educational Success, A Love of Learning, A Chance to Succeed. http://www.education.gouv.qc.ca/fileadmin/site_web/ documents/PSG/politiques_orientations/politique_reussite_educative_10juillet_A_1.pdf

Ministère de l'Éducation du Québec (MEQ). (1998). A School for the Future: Policy Statement on Educational Integration and Intercultural Education. http://www.education.gouv.qc.ca/ file admin/site__web/documents/dpse/adaptation_serv_compl/ PolitiqueMatierelntegrationScolEduclnterculturelle_UneEcoleAvenir_a.pdf

Nieto, S. (1999). Critical Multicultural Education and Students' Perspectives. In S. May (Ed.), Critical Multiculturalism: rethinking multicultural and antiracist education (pp. 191-215). London: Falmer Press. 
Nieuwenhuis, J. (2010). Social justice in education revisited. Education Inquiry, 1(4), 269-287. https://doi.org/10.3402/edui.v1i4.21946

Patton Davis, L., \& Museus, S. D. (2019). What Is Deficit Thinking? An Analysis of Conceptualizations of Deficit Thinking and Implications for Scholarly Research. Currents, 1(1), 117-130. http://dx.doi.org/10.3998/currents.17387731.0001.110

Potvin, M. (2017). L'éducation antiraciste, inclusive et aux droits dans le développement des compétences professionnelles du personnel scolaire et des capabilités des élèves. Éthique en éducation et en formation. Les Dossiers du GREE, (3), 97-121. https://doi.org/ 10.7202/1042939ar

Potvin, M. (2014). Diversité ethnique et éducation inclusive : fondements et perspectives. Éducation et sociétés, 1(33), 185-202. https://doi.org/10.3917/es.033.0185

Rhedding-Jones, J. (2010). Critical Multicultural Practices in Early Childhood Education. In M. Stephen \& C. E. Sleeter (Eds.), Critical Multiculturalism: Theory and Praxis (pp. 73-85). London: Routledge.

Stokke, C., \& Lybæk, L. (2018). Combining intercultural dialogue and critical multiculturalism. Ethnicities, 18(1), 70-85. https://doi.org/10.1177\%2F1468796816674504

Vermersch, P. (2017). L'entretien d'explicitation. Paris : ESF Éditeur. 